\title{
Practice, Immersion and Collaboration - the Teaching Exploration of the Integration of Traditional Culture Into Art Design Course From the Constructivism Theory
}

\author{
Qiong Xie ${ }^{1, *}$ \\ ${ }^{1}$ University of Shanghai for Science and Technology, Shanghai, China \\ *Corresponding author. Email: 17614717@qq.com
}

\begin{abstract}
This paper mainly analyzes and discusses the necessity of integrating traditional culture into the professional education of Chinese contemporary art design, the current situation of integration, and the ways of integration, and summarizes the practical experience of integrating traditional culture of Chinese contemporary design education into the exploration process. Through the analysis of the current situation and the elaboration of practical cases, the problems and experience in the combination of art design and traditional culture of Chinese public universities are discussed. This paper summarizes the urgency of integrating traditional culture into modern design education in China and its promoting role in the development of Chinese contemporary design.
\end{abstract}

Keywords: traditional culture, integration, design education

\section{INTRODUCTION}

The process of modern art design is a process of improving the sense of vision, touch, hearing, smell, experience and so on. Its research contents and service objects are often aimed at a demand object, which is different from the traditional pure art creation process. At the same time, art design is a comprehensive subject, which involves many factors such as society, culture, economy, market, science and technology. China has a long history of more than 5000 years on the splendid civilization. The inheritance and development of these excellent cultures are conducive to the cultural development of human beings and the promotion of the cultural and artistic exchanges between China and the world. As we all know, visual elements can spread faster than text elements, and national boundaries are less hindered. Art design is an effective channel for more ordinary people and experts and scholars from all over the world to understand Chinese traditional culture more smoothly through the refinement and creation of visual symbols and the expression of international visual language.

\section{THE NECESSITY OF INTEGRATING TRADITIONAL CULTURE INTO ART DESIGN EDUCATION}

\section{A. Traditional culture provides content source for art design creation}

Viewing the outstanding works of Chinese and international art and design disciplines, most of them have strong cultural background. Works divorced from the cultural connotation may temporarily attract the attention of the public, but they can hardly stand the test of the long history. And many works based on traditional cultural innovation design are more easily accepted by the world, and can also have the characteristics of recognition and memory. For example, Ieoh Ming Pei, a world master of architectural design, integrates Jiangnan culture and literati's ink painting into architectural design, creates Suzhou Museum in civilized world and applies Egyptian pyramid form to Louvre in Paris, which embodies traditional culture and gives strong inspiration to modern design. For example, Kan Tai-keung, Hong Kong famous designer, used Chinese traditional ink elements in modern poster design, and he was rated as outstanding artist and designer by western design circles.

In the world, various traditional cultures provide numerous design think tanks for art and design creation, 
and have also laid a foundation for the blooming of creative forms. Only through the in-depth study and application of all kinds of traditional culture can we create more interesting design works.

\section{B. Traditional culture provides aesthetic basis for artistic design creation}

Art design has various forms, contents and categories. The author has been engaged in the teaching and research of visual communication design for a long time. Through teaching practice, it is found that for the learning of excellent traditional culture and art aesthetic education courses started by freshmen, students will actively carry out a broader inquiry based autonomous learning, and find more visual expression and artistic means in the learning process. For example, the works of the designers of the Academy of Art and Design of Tsinghua University have been used as illustrations on front page by overseas edition of China Daily for many times. Various traditional Chinese aesthetic ideas, such as Chinese traditional auspicious patterns, line drawing of figures, scattered perspective of Chinese paintings, are reflected in these works. His works have been praised by many media in China and foreign countries.

The best way to apply the design in a certain region is to combine the traditional culture of the region organically, so as to have a better communication affinity. It is just like the principle that foreigners can learn local dialects and communicate with others more quickly to gain the acceptance of the natives. For example, Coca Cola, as an international big brand into China, has created a lot of works containing Chinese humanities and art content and is loved by the Chinese public.

\section{RESEARCH ON THE INTEGRATION OF TRADITIONAL CULTURE INTO COLLEGE ART DESIGN}

With the further influence of all kinds of Chinese traditional culture in the world culture and education field, from the overall point of view, the output of Chinese culture has achieved remarkable results. The achievements of cultural studies have been significantly improved. Under the guidance of traditional Chinese culture, various disciplines have joined in the construction of the integration system of traditional culture. The teaching of specialized courses in colleges and universities is changing from the unitary teaching of "professional courses" to the diversified integration of humanistic values". However, with the influence of various practical factors, there are still some problems in the integration of traditional culture into university art design courses, which restricts the construction of the teaching system of "integrating traditional culture" in art design major of colleges and universities. Through the analysis on the current situation of art courses in universities, this paper specially analyzes the existing problems. For example, the design teachers, especially some young teachers, do not understand or care about and pay no attention to Chinese traditional culture. Teachers lack the understanding of the concept of integrating traditional culture into professional education. In the narrow sense, the integration of traditional culture is a simple study of design history, and there is a certain psychological conflict. In view of such problems, it is suggested that colleges and universities should organize the introduction of excellent demonstration courses in China and foreign countries and the network promotion of highlights, so as to facilitate art and design teachers to understand traditional culture, traditional aesthetics, cultural inheritance, innovation and development, international exchange, etc. originally existed in the teaching content of professional courses for a long time. It is required to get in-depth understanding as soon as possible. Once there was a saying that "what China owns is what the world owns", expressing that only those with the cultural heritage can it be truly accepted by the world. Only by learning the excellent design methodology of other countries and applying it to the cross-media communication of China's excellent history and culture in the new era, can we further promote the systematization development of the new generation of Chinese traditional culture. On the other hand, students of art and design majors mostly focus on all kinds of global culture and are influenced by various cultures. They have a higher pursuit of their own attainments and artistic standards. Compared with other majors, they have a relatively unique perspective on the cognition of things and attitude towards the world. Selfconsciousness is prominent, perceptual thinking is strong, and rational thinking is weak. They are not sensitive to the content of Chinese traditional culture, and emphasize learning by feeling. It also hinders the smooth progress of the integration of traditional culture.

\section{WAYS TO INTEGRATE TRADITIONAL CULTURE INTO COLLEGE ART AND DESIGN COURSES IN THE ERA OF MEDIA CONVERGENCE}

After fully understanding and recognizing the importance of integrating traditional culture into teaching, teachers find a teaching mode suitable for the current situation of "Internet $+"$. According to the theory of constructivism, "constructivism holds that knowledge is not acquired through the teaching of teachers, but by the help of other people (including teachers and learning partners) in a certain situation, that is, under the social and cultural background, learners can obtain knowledge by means of meaning construction. The integration of traditional culture into education content of art courses can rely on constructivism theory to form an explicit and implicit training mode. 


\section{A. Presetting the content of traditional culture and innovating practical content}

With the coming of the new media age, a group of products in new media era represented by WeChat movements, live-broadcasting platform, Weibo, official account and teaching platform have gradually emerged in people's lives and become a vital means for people to communicate, entertain themselves, study and work every day. Through the above analysis on the integration of traditional culture of art courses in today's universities, it can be seen that both modern culture and traditional culture have a low sense of existence in the teaching of art courses, and the degree of attention and cooperation between teachers and students are not good. In order to effectively solve this problem and build a good atmosphere for the effective implementation of the integration of traditional art culture into education, colleges and universities need to make use of the powerful information transmission of new media, increase the publicity of the integration results of excellent traditional culture, help teachers and students to actively change their ideological understanding, and help teachers and students understand the close relationship among traditional culture, innovation, artistic value and artistic quality. Specifically, universities can publish some hot topics related to the art design industry regularly by using the school's official website, etc., and carry out traditional educational propaganda activities by using the livebroadcasting platform. The official account of WeChat is used to release the related movements of the art and design industry to teachers and students regularly, so as to deepen the understanding of the importance of traditional culture and education between teachers and students.

\section{B. Traditional culture needs to carry out immersive experience of content}

The expansion of teaching content can enrich students' cognition of traditional culture learning to the greatest extent, and then students can see the charm of traditional culture from different perspectives. Especially in view of the reality of outstanding individuality of art and design students, the single traditional culture teaching content is too boring to arouse students' high interest in learning. In the face of the advent of the new media era, colleges and universities should actively make use of the advantages of new media to provide students with rich and colorful teaching content, so as to meet the ideological and political learning needs of students majoring in art and design. The author is in the south of the Yangtze River in China. And famous scholars and experts of Jiangnan culture are invited to give lectures in the university. Together with professional teachers, they can guide students to complete modern design works related to Jiangnan culture in the "double tutors" model, so that students can experience what Jiangnan culture is. For example, the professional teachers will lead students to the intangible cultural heritage bases in China to experience and learn all kinds of intangible cultural heritage handicrafts. Through their own practice, students will create relevant design works with modern design methods based on the theme. The excellent design works with typical Chinese elements are formed.

Specifically speaking, first of all, art teachers are required to have very keen observation ability, and be able to accurately capture the profound cultural connotation and significance contained in Chinese traditional culture. Teachers should introduce these excellent cultural contents into the students' vision in various forms, such as WeChat official account, micro video, etc. Secondly, teachers should pay attention to the combination of modern design means, guide students to pay close attention to the international design trend, and open a window of design for art majors to realize their rational cognition of the world, traditional culture, design methodology and self. Therefore, it points out the direction for the good development of students' future art design career, so that they can effectively improve the design level through the learning and integration of cultural knowledge and design skills, and better transmit the culture to the world for cultural output.

\section{Carrying out collaborative training with multiple forces to achieve traditional culture implantation}

Compared with other majors, the ideological and political content of art courses is more colorful. It includes the modern design expression of traditional culture, the cultivation of designers' sense of social responsibility, and ways to improve the understanding of Chinese culture in the world through design. With so much content, it is far from enough to rely on the teachers of the school itself. Therefore, it is required to make the cultivation with social forces and resources. The university can cooperate with the inheritors of Chinese intangible cultural heritage, traditional culture researchers, foreign cultural exchange directors and other relevant scholars and experts to conduct on-site teaching, forming a joint-training mechanism of "double tutors". Also, the university can establish training bases with Chinese important museum groups, inheritance bases of intangible cultural heritage, and various traditional culture research institutes to form a long-term co-construction training mechanism. And then, the university can provide the soil for art students to broaden their horizons and cultivate their comprehensive cultural quality.

\section{CONCLUSION}

To sum up, the new media provides a new way of education for the integration of traditional culture into 
the education of university art courses, which not only enriches the materials of traditional culture education, but also broadens the education channels. It is an important content for colleges and universities to actively comply with the development needs of the times and use new media to carry out traditional culture education of art and design in universities. In the future work, it is necessary to strengthen the analysis on the function of new media education based on the research of the characteristics and needs of traditional culture education of art and design, so as to do a good job in the organic integration of traditional culture of university art and design in the new media era.

\section{References}

[1] Wang Lifang. "The Integration of Traditional Cultural Elements and Art Design Professional Courses", Art Education Research. (in Chinese)

[2] Zhou Mengxi, Wang Rui. "The Application of Traditional Culture in the Creative Education of Art Design Major", Drama House. (in Chinese)

[3] Gong Min. "Teaching Innovation Introducing Local Cultural Elements into University Environmental Art Design Education", Design Research. (in Chinese)

[4] Yu Xiaoqin. "Research on the Teaching of "Design Semantics" Course Adhering to the Connotation of Chinese Traditional Culture in Art Design Major". Art and Literature for the Masses. (in Chinese)

[5] Wang Xinye. "Analysis and Strategic Research on the Current Situation of China's Art Design Major", Art Education Research. (in Chinese)

[6] Qiu Haidong, Lei Jieqing. "Application of Brocade of Li Minority to Art and Design Education in Universities", Hundred Schools In Arts. (in Chinese) 